\title{
Profile of producer and retailer of flower and ornamental plant
}

\author{
Michele Valquíria dos Reis ${ }^{1^{*}}$ (D), Gabriela Silva Sant'Ana ${ }^{1}$ (D), Patrícia Duarte de Oliveira Paiva ${ }^{1}$ (D), \\ Francilene de Lourdes Bonifácio ${ }^{1}$ (D), Paulo Henrique Sales Guimarães ${ }^{2}$ (D) \\ ${ }^{1}$ Universidade Federal de Lavras (UFLA), Departamento de Agricultura, Lavras-MG, Brazil. \\ ${ }^{2}$ Universidade Federal de Lavras (UFLA), Departamento de Ciências Exatas, Lavras-MG, Brazil
}

\begin{abstract}
The importance of segment of flowers and ornamental plants in agribusiness are growing. Researches that analyze the situation of different sector of this segment may contribute to establishing politics and actions to stimulate its development. In order to attend this purpose, the aim of this research was to analyze segments of the flower and ornamental plant production chain, focusing on producers and retailers. For that, two different surveys were applied, composed of direct and indirect questions. The application was performed online, using social media or in person, in the company location or in trend fairs. It was observed that the flower and ornamental plant production is mainly a familiar business. Another important issue is that the springtime consists of a new date for flower and ornamental plant commercialization. The number of retailers has been increasing, and this segment had some improvements as sales of different products and services. The flower and ornamental plant commercialization are still, in the majority, in physical location shops, besides of all the technologies available for online sales.
\end{abstract}

Keywords: agribusiness, productive chain, flower commercialization, flower and ornamental plant market.

\section{Resumo}

Perfil do produtor e varejista de flores e plantas ornamentais

A importância do segmento de flores e plantas ornamentais no agronegócio está crescendo. Estudos que analisam a situação dos diferentes setores desse segmento podem auxiliar a entender e estabelecer políticas e ações que apoiem e estimulem o seu desenvolvimento. Para atender a esse propósito, objetivou-se analisar segmentos da cadeia produtiva de flores e plantas ornamentais com foco em produtores e varejistas. Para isso, foram aplicados dois questionários diferentes com perguntas diretas e indiretas. A aplicação foi feita de forma online, por meio de mídias sociais, ou por abordagem presencial nas propriedades e em feiras tecnológicas da área. Identificou-se que o perfil dos produtores de flores e plantas ornamentais ainda é, em sua maioria, um negócio familiar. O período de primavera passou a ser uma nova data relacionada ao pico de produção e venda. O número de floriculturas, floras e Garden centers aumentou, e esses passaram a oferecer uma maior variedade em produtos e serviços. A comercialização ainda é feita em sua maioria, em lojas físicas, mesmo considerando a tecnologia associada a venda de produtos online.

Palavras-chave: agronegócio, cadeia produtiva, comercialização de flores, mercado de flores e plantas ornamentais.

\section{Introduction}

Flower and ornamental plant are promising segments of Brazilian agribusiness, and it is also an activity of great prominence in the economy of several countries. The great expansion of the Flower and Ornamental Plant is especially due to the positive socioeconomic situation and the increase in consumption (Junqueira and Peetz, 2017). The flower and ornamental plant market turnover a total of R\$ 7.9 billion in 2018, with an estimated increase of $8 \%$ to $10 \%$ in 2019 in Brazil (Ibraflor, 2019).
This agribusiness segment is composed for Production, Wholesale, Distribution, Retail, and Consumer sectors. Production consists of small, medium and large producers, with the function of supplying all the market demands, leveraging the entire production chain (Landgraf et al., 2009a; Landgraf et al., 2009b; Silva et al., 2015). Brazil has more than 8,000 flowers and ornamental plants producers, cultivating more than 350 species and 3000 cultivars. The production occupies around 15,000 hectares and directly employs 78,000 people. A part of this, the area of grass cultivation in Brazil is around 25,000 hectares (Ibraflor, 2019).

"Corresponding author: michele.reis@ufla.br 
The retail sector employs over 120,000 people and has the responsibility of sales directly to the final consumer, being linked to marketing actions and promotions to stimulate and increase the consumer sector. The retail is composed of different means of commercialization, such as nurseries that sell seedlings and other garden products, the selling point, such as supermarkets where flowers, potted foliage, and bouquets are usually found, Flower shops that may be specialized in cut and potted flower and foliage or to cover a wider range of products, including garden supplies, and Garden Centers that are big or huge structures, mainly selling plants and garden supplies (Landgraf et al., 2009a; Landgraf et al., 2009b; Junqueira and Peetz, 2014).

In addition to the traditional retailers, the use of social media both for sales and for the promotion of products has been highlighted and has a direct influence, increasing sales (Li and Lei, 2016; Rombach and Bitsch, 2016). In this way, the search for novelties has also increased and, as a consequence, there are actions for stimulating and or inducing purchase. Also, there is a great convenience in purchasing through the internet, through which the customer has direct access to the desired product, receiving it at their address.

Regarding the kind of produced and commercialized products, the segment is divided into plants for landscaping and gardening (42\%); cut flowers and foliages (34\%); and potted flowers and foliages (24\%) (Landgraf et al., 2009a; Landgraf et al., 2009b; Junqueira and Peetz, 2017). Consumption is concentrated on commemorative dates, with greater demand on Mother's Day, All Souls' Day, Christmas, and Valentine's Day. For that, commerce is required to make available greater supply and diversity of products to attend the consumers (Ceratti et al., 2007).

However, most of the information on the production e retail sector is not current, making planning of the sector difficult. In order to better understand the profile of the flower and ornamental plant market in Brazil, focusing on production and retail segments, a survey was carried out to identify the main characteristics of each profile.

\section{Material and Methods}

The survey was carried out through the application of structured questionnaires with specific questions to each profile. The aim was to get knowledge of the main aspects of the sector, including the limitations. A total of 159 peoples were interviewed ( 80 from retail and 79 producers), from all regions of Brazil that responded spontaneously to the questionnaires.

The questionnaires were applied in-person and online. For the in-person survey, producers and owners of flower shops were interviewed, in their properties, establishments, cooperatives, during specialized fairs such as Hortitec and Enflor Garden Fair. Wide dissemination was also made on social media such as Facebook, Instagram, and emails with support of the Brazilian Society of Floriculture and Ornamental Plants, aiming to reach a large number of responses, diversity of origin and profile of the respondents. The online questionnaires were made available on the
Google platform and the access was through two different links, directed to each sector (retail and producers). The survey period ranged from September 2017 to September 2018. Aiming for impartial results, respondents were not identified.

The questions and possible answers were elaborated in simple language, without the use of technical terms, avoiding any type of misunderstanding. Most of the questions have direct, single or multiple answers, but for a few of them, depending on the theme, respondents were allowed to free answers.

\section{Producers sector}

In order to characterize the first stage of the Flower and Ornamental Plant production chain, the questionnaire addressed to producers involved questions such as: In which state of the country is the production area located and, concerning the company's headquarters, the information of the number of inhabitants of the city. For the owner profile characterization, questions to inform gender, time in the activity, and reasons that led to starting this activity. Concerning the company's performance, the interviewed were encouraged to inform the range of the products available to sell and which species were most cultivated; whether there was interest in diversifying products; the period of the year with the greatest demand; the limitations during the production process. They were also asked to inform about the expansion of production in the last five years. Another requested information was whether there was participation in any type of professional updating course or any kind of training.

\section{Retail Sector}

In order to characterize and built the profile of the retail sector, owners were asked about the type of company (flowers shop, garden center, selling point, or other they owned) and its structure: number of employees; annual income; and the average amount spent on purchases by customers. Other questions were concerning the State of the company's location and, the establishment's headquarters, informing the number of inhabitants of the city.

In order to characterize the owner's profile, questions about the gender, time in the activity, reasons for starting the activity in flower and ornamental plant business, and whether there is some kind of professionalization or training on the part of the owner.

Aiming to learn about the performance retail in the market, they were encouraged to inform the most commercialized products, whether or not there was difficulty in finding products, the number of employees and, among these employees, how many belong to the owner's family. It was also asked if there is an interest in modifications or expansion in the coming years.

The data collected and recorded through the questionnaires were compiled and each set of question/ possible answers was analyzed. The questions were evaluated using the statistical software, R Core Team, using an association between qualitative variables (ChiSquare Test, Relative Risk, and Chance Ratio). 


\section{Results and Discussion}

In this research, respondents from different regions of Brazil were obtained, with $8.3 \%$, from the Northeast, $4.3 \%$ from the North, 7.0\% from the Midwest, $69.7 \%$ from the Southeast and $10.7 \%$ from the South. According to Ibraflor data, the southeast is the main region for the production and commercialization of flowers in Brazil. Approximately $49 \%$ of producers $(4,018)$ and $57.1 \%$ of retail outlets $(8,561)$ are located in this region of the country (Ibraflor, 2019). The largest numbers of respondents was from the states of MG and SP, where also concentrate most of the flower and ornamental plant production area.

\section{Producers sector}

Most of producers are located in cities with 10,000 to 50,000 inhabitants, followed by 50,000 to 100,000 inhabitants (Figure 1) indicating to be medium-size cities. Since a smaller number of productions are in large cities (over 500,000 inhabitants, 5.1\%), this confirms that smaller cities are responsible for supplying large centers.

Analyzing the interviewed profile, the majority (64.6\%) of the properties are owned by men (Figure 2). In the 2017 Agricultural Census it was presented that only $19 \%$ of rural properties belong to women (IBGE 2020).

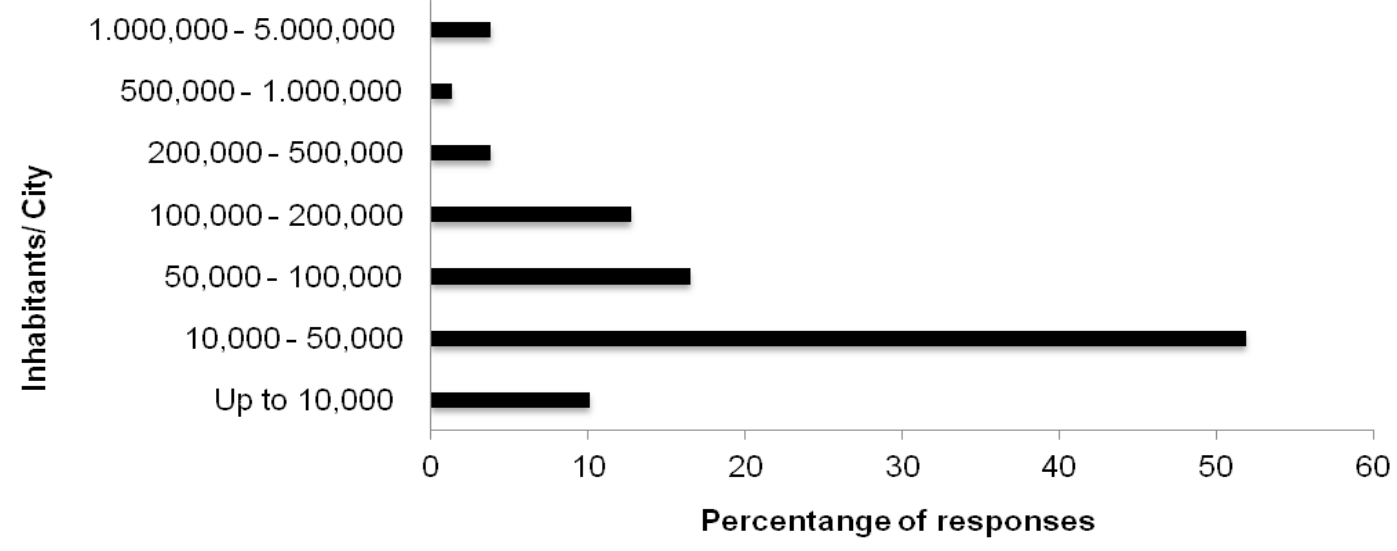

Figure 1. Number of city inhabitants from the company's headquarters location.

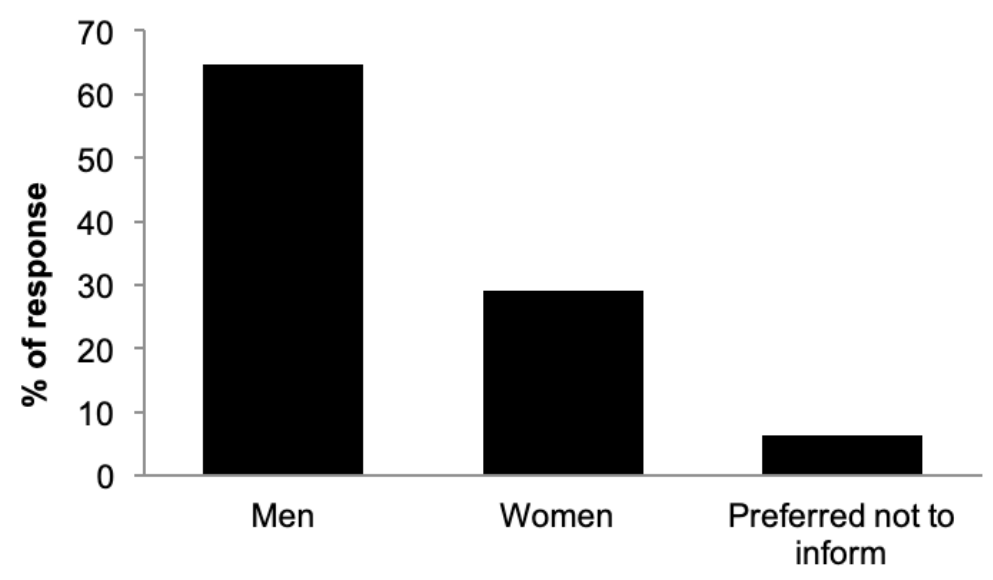

Figure 2. Gender of the owners of flower and ornamental plant production.

But this does not exclude that women have been playing an important role in this activity. The number do women working in the flower industry is high. Women are preferred to work with the flowers, due to the greater care and delicacy during all stages of handling the flowers Also, the floriculture industry can play a important role in women empowerment (Pusa and Giribabu, 2016; Padmini and Kodagoda, 2017), making them more economically independently.
Concerning the number of workers on the property, there is only one in $8.9 \%$. In $32.9 \%$ of the properties, are employed 2-5 person and in $13.9 \%, 5-10$. This allows indicating that in $46.8 \%$ of the property owner up to 10 workers and in other $31.1 \%$, more than 10 workers. Another interesting observation is that for $3.9 \%$ of the interviewed, more than 150 workers are owned. This characterizes a great diversity of the production companies, from small to a huge size. 
The producers have been active in the flower and ornamental plant trade market for an average of 15 years, but $41.8 \%$ have been producing for more than 20 years. On the other hand, the number of new companies, which operate from up to 3 years in the market, was significant, corresponding to $13.9 \%$ of respondents. Considering that the growth of the floriculture activity in Brazil is around 6\%-7\% per year (Junqueira and Peetz, 2018), the increase in ornamental plant production companies in the last 3 years is higher than the registered growth of the activity.

The flower and ornamental plant activity is considered to be one of the most profitable segments and has been attracting many investors. The reasons or motivations that stimulated investment in the activity were identified. It was observed that $43 \%$ attribute to the performance in the trade market, since this is a familiar activity, and another $38 \%$ consider this activity as a potential trade market, once again confirming that this market is expanding (Figure 3).

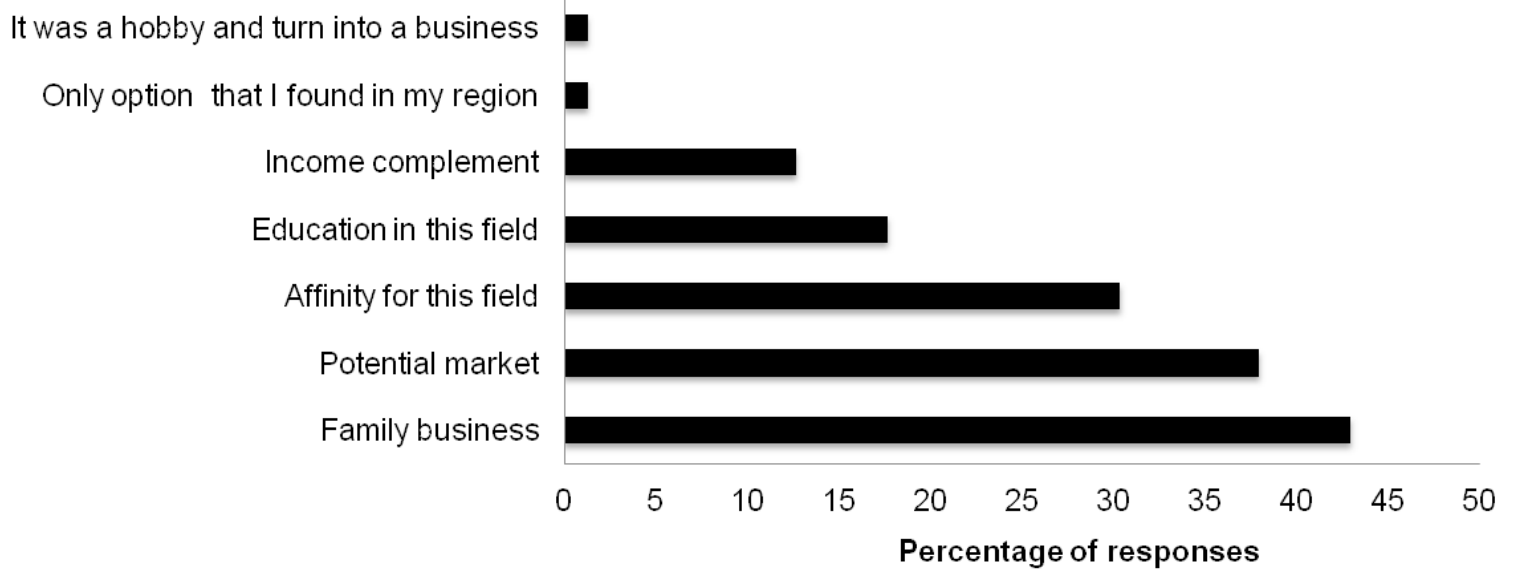

Figure 3. Motivations for acting on flower and ornamental plant production sector (multiple answers).

Another interesting factor is that the activity is carried out for family reasons, that is, the production is a family inheritance. In Brazil, only $36 \%$ of the companies survive to the transition to the second generation; $19 \%$ for the third generation; 7\%, for the fourth generation; and only $5 \%$, for the fifth or more generations (IBEF-SP, 2011). Thus, the reason alleged by $43 \%$ of respondents exceeds the national expectation of $36 \%$ of companies to be inherited.

It is interesting to notice that education in this field was a factor indicated as the reason for starting the production activity for $17.7 \%$ of the interviewed. This demonstrated the importance of universities in preparing professionals in this field of knowledge. Another interesting factor is that the activity is carried out for family reasons, that is, production is inherited from parents to children, who continue to work on this activity. Among the interviewed, only $12.7 \%$ indicated that their interest in activity was for complementing their income as a second business option.

Considering the species most cultivated, the producers informed that most of them work in the production of cut flower, followed by potted plants (Figure 4).

Inside the category of cut flowers, the main flowers quoted by the producers were rose, chrysanthemums and alstroemeria (Table 1).

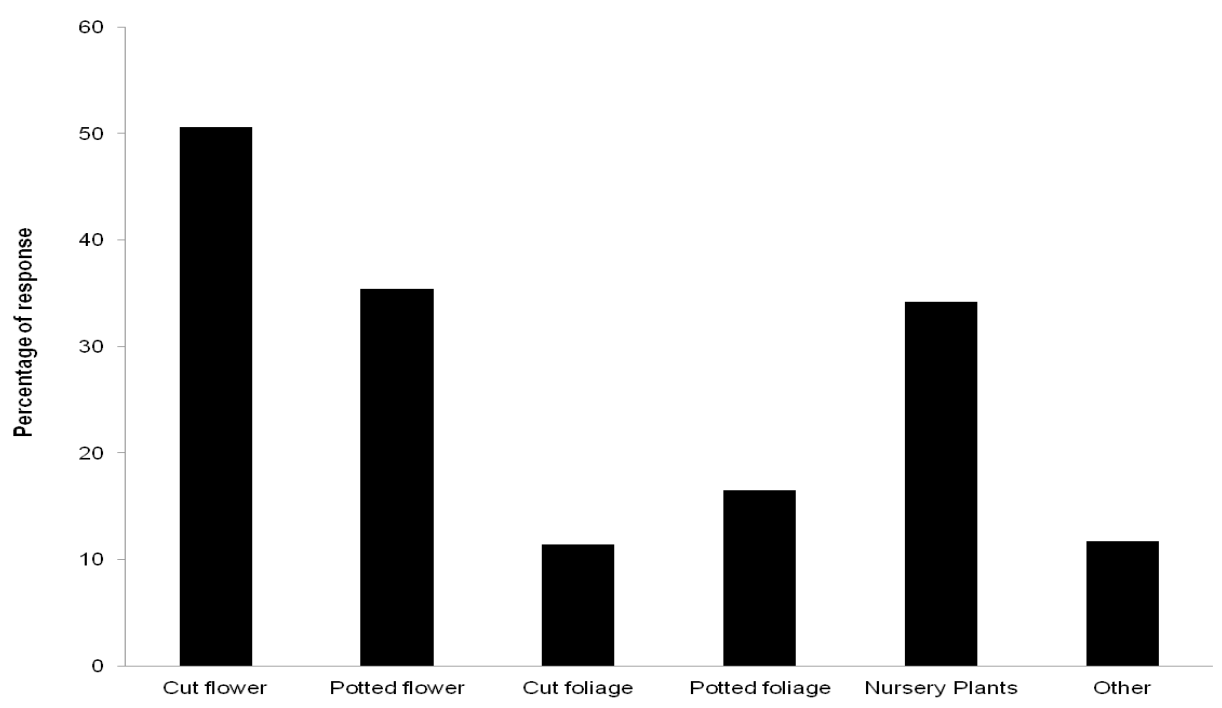

Figure 4. Groups of flowers and ornamental plants most cultivated by the interviewed. 
Table 1. Plants most quoted by the interviewed in each group of flower and ornamental plant.

\begin{tabular}{|c|c|c|c|}
\hline Products group & & Plants most indicated in each group \\
\hline Cut flower & Rose & Chrysanthemum & Alstroemeria \\
\hline Potted flower & Orchid & Cyclamen & Anthurium \\
\hline Cut foliage & Fern & Cordyline & Myrtle \\
\hline Potted foliage & Fern & Sansevieria & Palms \\
\hline Nursery Plants & Rose & Palms & Cyca \\
\hline Other & Succulents & Everlasting flowers \\
\hline
\end{tabular}

Roses have a long and colorful history as symbols of love and beauty. Rose have been referred to as the queen of flowers; this is attributed to its beauty, variety of colors, sizes, and versatility. Besides, roses are one of the flowers widely used by the florists in decorations and in bouquet composition. For retailers, especially on commemorative dates, the rose has greater demand since this species represents feelings like love and affection (Ceratti et al., 2007). Due to that, $86.7 \%$ of the rose's sales are for gifts (Anacleto et al., 2017). In recent years, the alstroemeria production has been grown considerably (Ibraflor, 2019) and gaining more and more space in the market, mainly due to the flower beauty and postharvest durability.

Among the potted flowers, orchids, ciclâmen, and anthurium are the preferred by the producers. The orchids in general have high potted durability, in special the phalaenopsis that can be flowering for months and also have different flower colors that attract many consumers. A report from Ibraflor (2019) highlighted that phalaenopsis is by far the largest orchids species produced in Brazil. Among the species mentioned during the survey, it is important to highlight the production of cacti and succulents. Plants that have been grown in the flower market due to their ease of propagation and maintenance. Also, a group of consumers has the habit of collecting various species of cacti and succulents, orchids, and desert flower (Adenium). This behavior stimulates the trade market and also exchange practices, besides the development of groups associations on specific themes.

Producers reported that the greatest demands for the products occur on dates such as Mother's Day and Valentine's Day (Figure 5). This is one of the main characteristics of the flower and ornamental plant consumption in Brazil: sales are concentrated on specific dates (Junqueira and Peetz, 2017). Among them, Mother's Day is the main commemorative date for flowers sales (Aki, 2002; Ceratti et al., 2007). 


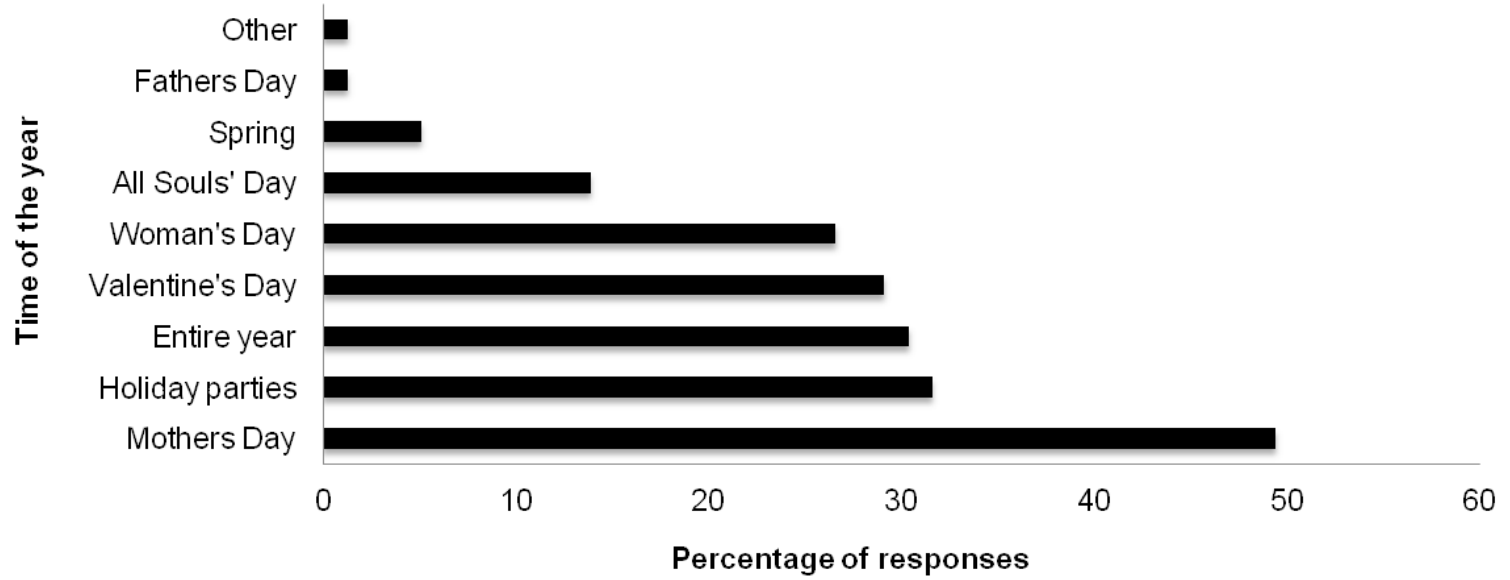

Figure 5. Period of greatest commercialization of flower and ornamental plant according to the producers (multiple responses).

Some producers, $30.4 \%$, consider that the production and sales are equal over the year. This may be related to the type of product produced since, for example, seedlings and plants for gardening are used and purchased independently of the commemorative dates.

It is interesting to observe that Spring is nowadays consider as a new period, with significant amount of floriculture products commercialization (Figure 5). This period of the year was not mentioned before as one important date for selling flowers and ornamental plants. Marketing campaigns that highlight the season characteristics (mainly focusing on nature, flowers, and fragrances) may contributed to this increase in sales, characterizing a new and great opportunity.

Analyzing the difficulties reported by the producers in developing the activity, the biggest limitations involved are in the economic-finances sector, including investment costs, taxes, and transportation charges (Figure 6). These issues use to be a common claim from seedling producers (Landgraf and Paiva, 2009b). Another issue corresponds to the low value paid to the products by the wholesale companies and other buyers, which is the complaint of $34.2 \%$ of the producers.

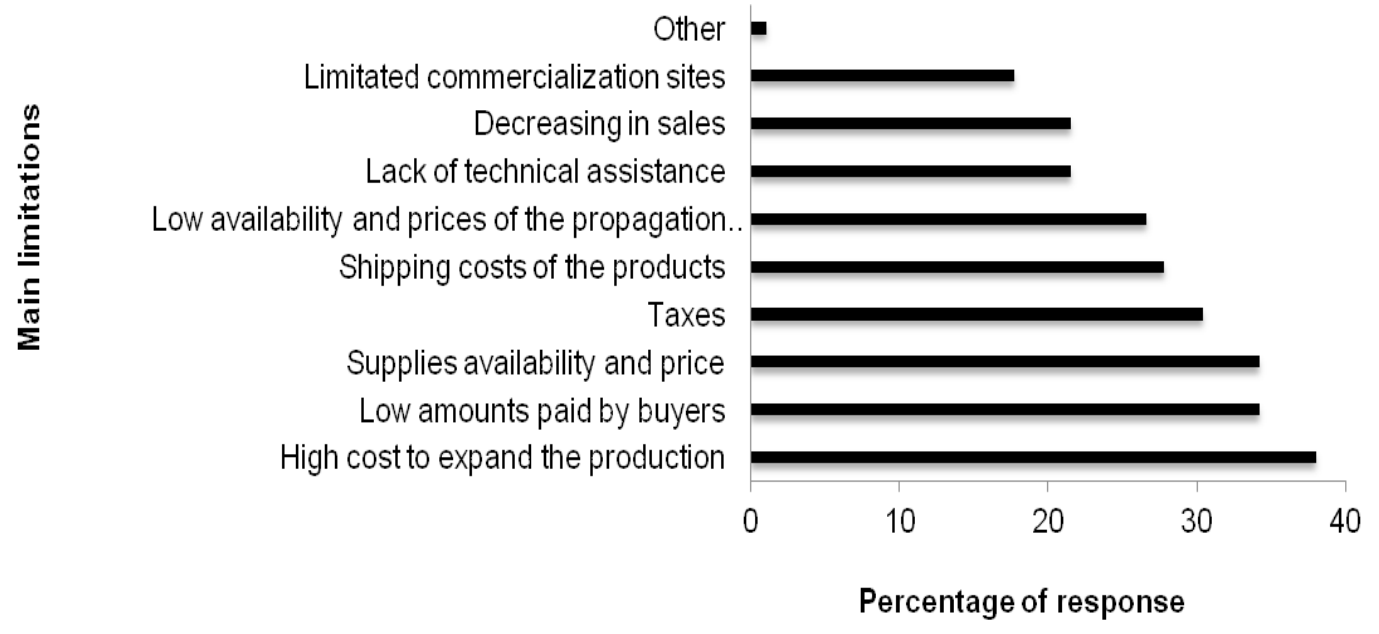

Figure 6. Limitations related by producers of flower and ornamental plant (multiple responses). 
The lack of specialized technical assistance was claimed by $21.5 \%$ of the producers. Considering the diversity of products and the fact that these are not include among the most important in the Brazilian trade balance, such as coffee and soybean, researches and professional training also occur in small numbers, reflecting in this limitation. However, some solutions must be thinking in order to minimize this problem.

\section{Retail Sector}

Although the number of respondents was not great, based on the responses obtained, it was possible to have an analysis of the profile and characteristics of the retailer segment. Most of the participants were from the southeast region (38.5\%), even though respondents from all the Brazilian regions provided information.

Regarding the number of inhabitants of the city (IBGE, 2020) where the company is located, it was identified that $42 \%$ were in small cities with up to 50,000 inhabitants, $45 \%$ in medium-sized cities, from 50,000 to 500,000 inhabitants, and $13 \%$ in large cities, with more than 500,000 inhabitants.

Considering the owners, $55.7 \%$ of the companies are owned by women and $40.5 \%$ by men, and another $3.8 \%$ preferred not to inform (Figure 7A).
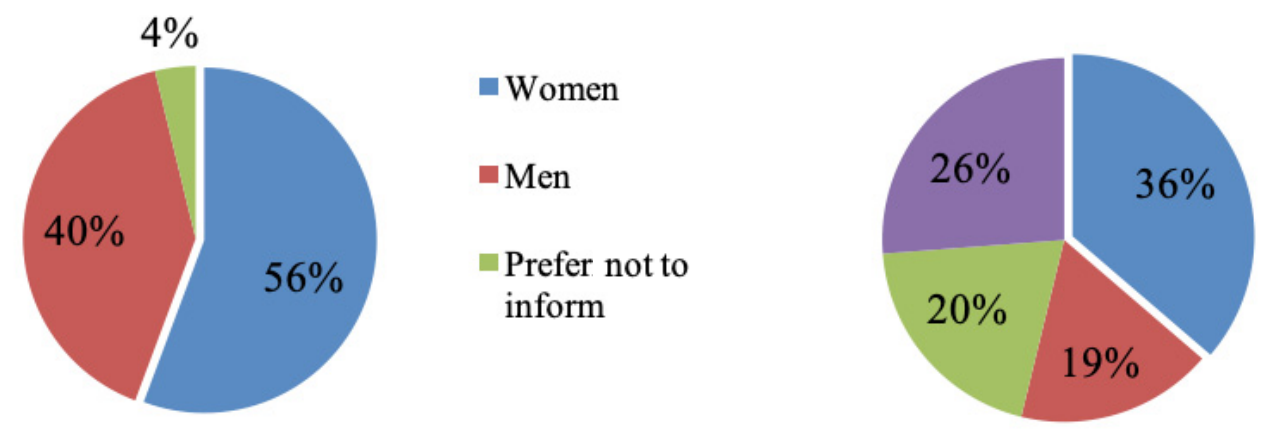

Less than 5 years

5 - 9years

$10-20$ years

More than 20 year

Figure 7. Gender of the companies' owners (A) and time acting in the business (B).

Analyzing the time in this business, 36\% informed less than 5 years. On the other hand, $46 \%$ have been working on it for more than 10 years (Figure 7B). It is possible to observe a considerable percentage of new companies on the market, indicating that the activity on the flower and ornamental plant retail sales has been grown gradually over the years. According to IBRAFLOR (2019), a total of 3,664 active flower shops were registered from all the Brazilian regions. Factors such as the internet promote the development of this activity, since it helps product promotion and marketing, raising the sales channels, besides the offer of some professional activities.

When consulted about the reasons that led them to start a floriculture business, most of them answer the selfaffinity and potential of this sector (Figure 8). A business family was the answer of $20.3 \%$, indicating that some are involved and attracted to continuing a yet established activity. Another situation to highlight is that this kind of business was an option for some professionals that had their education in this area as it was informed by $15.2 \%$ of the interviewed. 


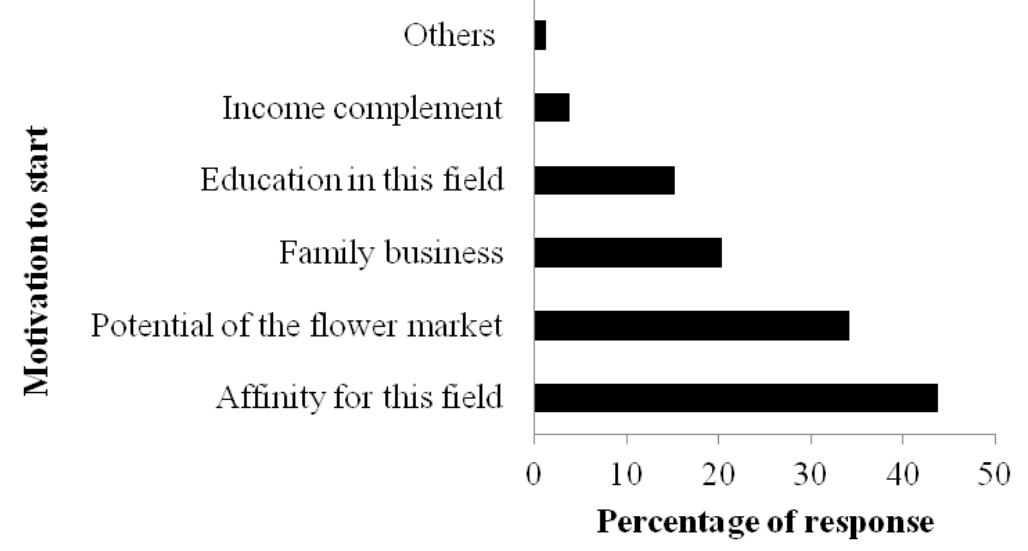

Figure 8. Motivations or reasons for starting retail business in flower and ornamental plant.

Concerning about the motivation to start the floriculture activity (Figure 8), education in the field) was the reason for more de $15 \%$. This indicates that the business owners have different backgrounds, which may sometimes limit the knowledge and information passed on to the client, in addition to the services provided. Both affinity for this field and potential market as set as the main reasons.
The limitation of non-formal education in this area can be compensated by the interest of the owners in events participation, such as exhibitions, congress and, also, in the acquisition of books, aiming to specialize and supply some knowledge and services necessary to better attend their customers. Thus, $59.5 \%$ indicated that they use to participate in specialized lectures and exhibitions, besides $27.8 \%$ that indicated the use of book acquisition (Figure 9).

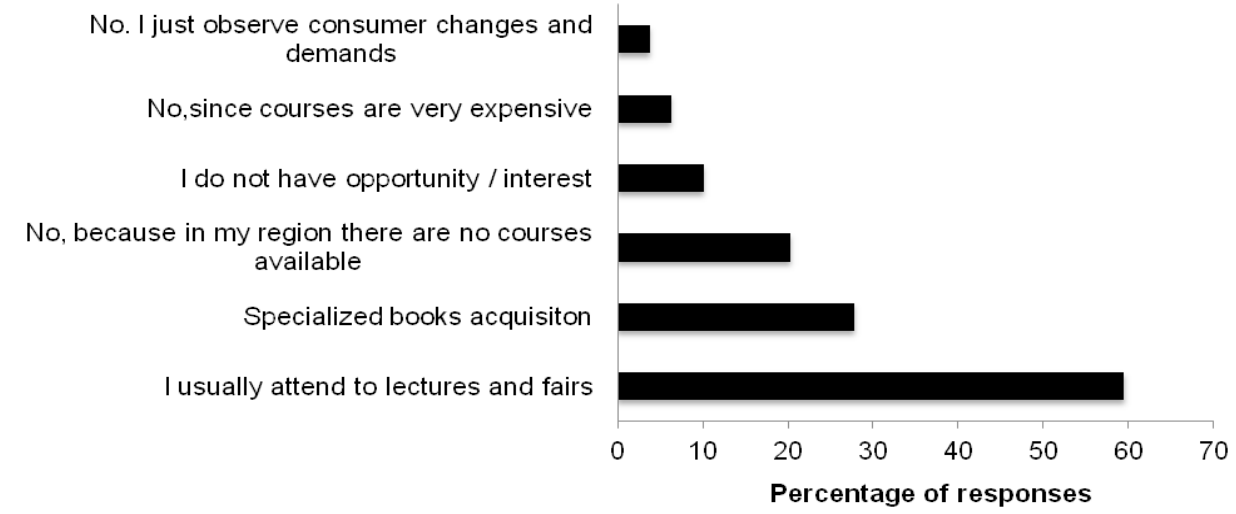

Figure 9. Attendance in courses, lectures, technical exhibitions by the flower and ornamental plant business owners (multiple responses).

It is interesting to note that $20.3 \%$ claim not to have the opportunity of attending any course, due to the unavailability in the region where the company is located. Also, it is a positive information that the cost is not bounding, since only $6.3 \%$ claimed as a reason for not qualifying. These results indicated a very interesting niche, considering the advent of some face-to-face and online courses in recent years. This kind of training has contributed a lot to the improvement in knowledge of this and other segments of the production chain.

Regarding the employees' framework, $30.8 \%$ have only one employee, and $51.9 \%$ employ $2-5$ persons. For $80 \%$ of the companies, there was a maximum of 5 employees, and only $7.6 \%$ have more than 10 employees. Among then, $41 \%$ of the employees' company has no familiar relationship with the owner, while for $59 \%$ of the enterprises, at least 1 (one) employee belongs to the owner's family.

It is possible to notice that most of respondents place their trust in family members to work and help on business. According to IBEF - Brazilian Institute of Finance Executives (2011), a family with a healthy relationship tends to have more prosperous businesses. Solid ties and mutual support help to encourage loyalty to the company, motivate people, and facilitate decision making. These issues indicate that the company is better prepared to raise good results and remain in the market. 
Assessing the profile of the flower shop owners, it was also possible to verify that the type of product purchases has been changing. Represented by $83.5 \%$ of the products sold out, consumers started to buy more cut flowers, such as roses, alstroemerias, lilies, gerbera
(Figure 10). This type of product previously used only for event decoration (parties, weddings, graduations ceremonies, etc.) has becoming part of the daily life, as an item of interest in home decoration, medical consulting rooms, and other.

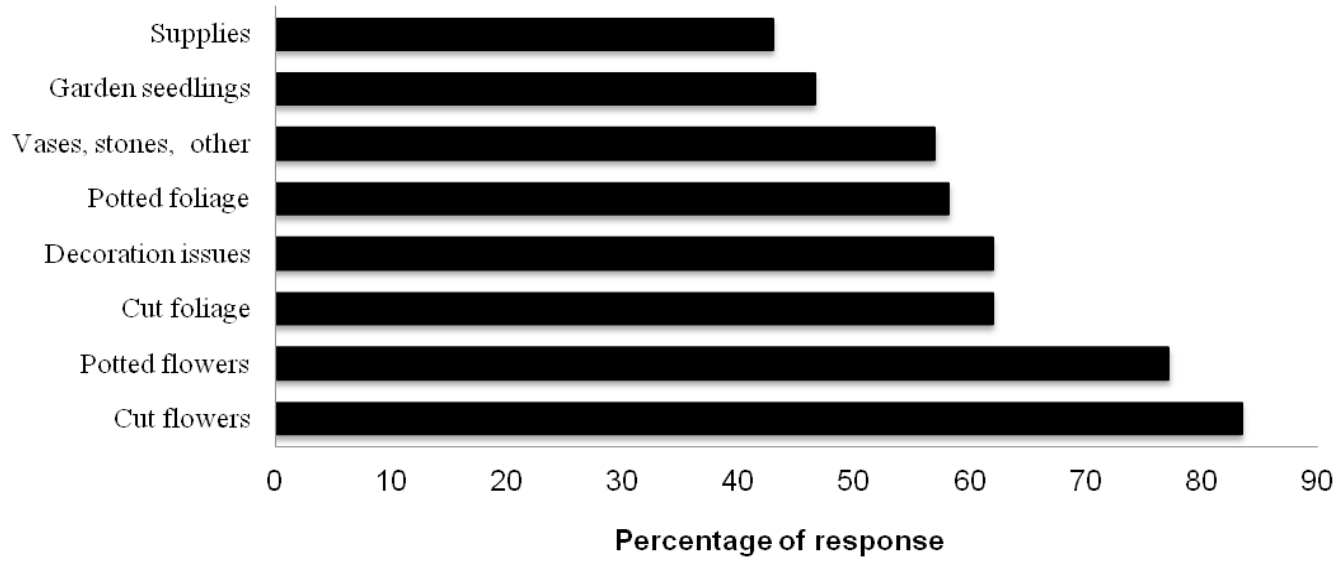

Figure 10. Products most commercialized in flower and ornamental plant retail sector (multiple responses).

Regarding the difficulty in finding the products to sell, $45.6 \%$ indicated that this do not happen, and for $45.6 \%$, only occasionally. Only $8.9 \%$ claimed that this was a problem for the retail sales of flowers and ornamental plants. This difficulty has been decreasing in line with the development and improvement of flower and ornamental plant distribution systems over the years. The owners of flower shops could find a greater variety of products available either from the wholesale or delivered by the distributors (Silva et al., 2015). The main companies of the wholesale sector were Veiling Holambra, CeasaCampinas, Ceagesp-ETSP, and Cooperflora that concentrate the distribution of flowers and ornamental plants, reflecting in a growth over than $\mathrm{R} \$ 732$ million / year (Silva et al., 2015). Ceaflor is a recent trade center opened (https://www.ceaflor.com.br/).

Analyzing the professional profile of customers, based on the flower shop owners' information, the three more commons are office workers, businessmen, and liberal professionals (Figure 11).

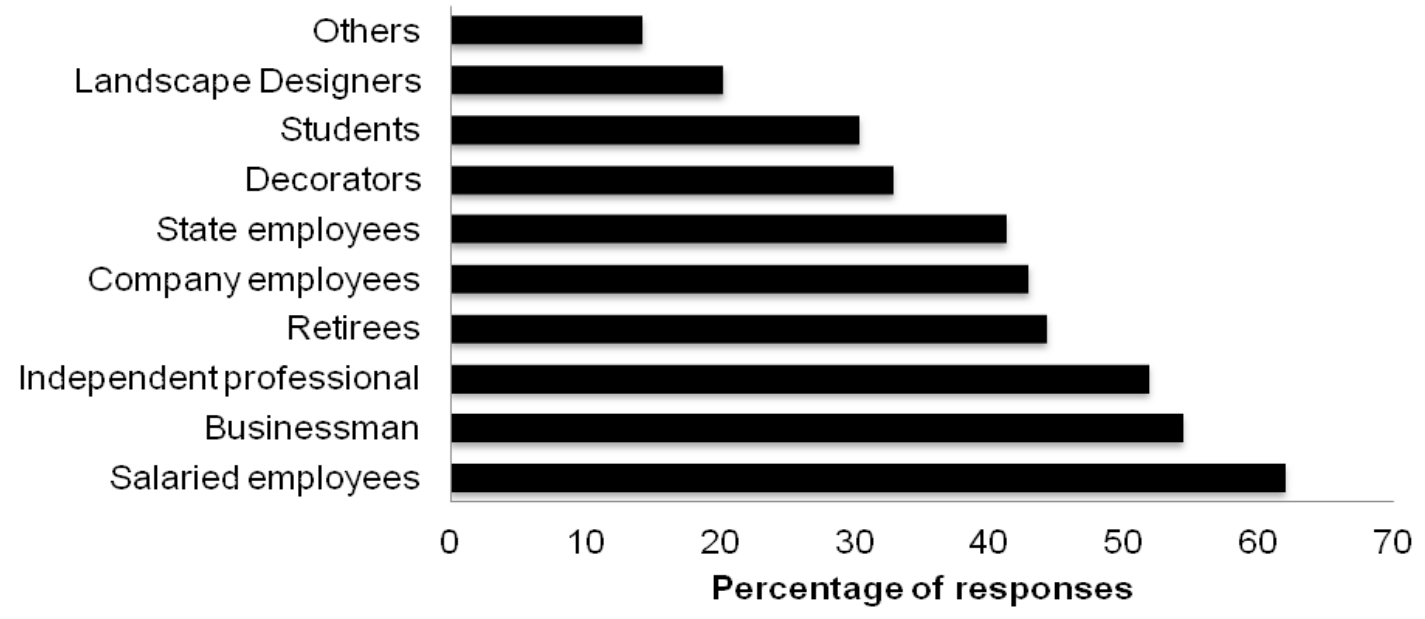

Figure 11. Professional profile of the customers according to the owners of the flower shops (multiple responses). 
The habit of purchase flowers and ornamental plants has become more common, but may be related to gender and age (Anacleto et al., 2017b; Lakshmi et al., 2017). Women with more financial independence, consume most flowers. That means, considering that flowers and ornamental plants are not considered items of basic necessity, the consumption may be due to their benefits as beauty and well-being (Aki, 2002). In this way, since women are more sensitive, also appreciate and value more these products. It was observed that $43 \%$ of the interviewed cited that the retired person consisting in an important group of customers of flowers and ornamental plants. The increasing number of elderly and their interest in this kind of product has been related as an important factor that influences the rise in consumption. Elderly tend to be more concerned with well-being, increasing contact with nature in their home, which improves the quality of life (Aki, 2002; Anacleto et al., 2017).

Another observation is that the segment of decorators and landscapers do not represents an important amount on sales. The main reason was that they usually acquire the products with lower price directly on the wholesale or by the distributors (Silva et al., 2015).

In order to understand the consumption profile, it was asked about the average value of each purchase, and the owners informed that expenses are mostlybetween $\mathrm{R} \$ 20.00$ and $\mathrm{R} \$ 50.00$, representing $27.8 \%$ of the owners' responses. It was observed that $3.8 \%$ of customers use to spend over R\$500.00 per purchase, that is a significant amount. This might occur mainly in stores where garden plants are the products sold since some seedlings of ornamental plants have a higher value. The average annual flower consumption in Brazil is $\mathrm{R} \$ 35.00$ per capita (Ibraflor, 2019).

Among the most sought-after products (Figure 12), it was observed that $51.9 \%$ of the owners of flower shops mentioned the potted flowers as the best seller product, due to the great durability and the possibility of, after decoration, be planted in a garden.

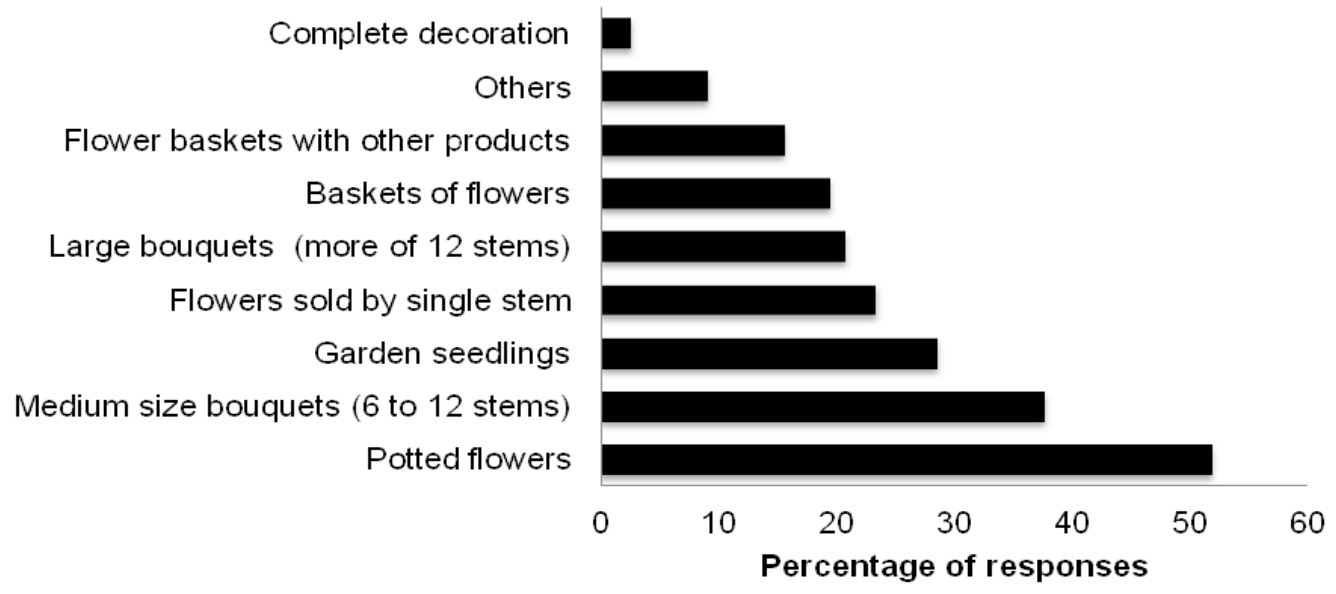

Figure 12. Products most sought-after by customers, according to the owners of the flower shops.

It was also possible to note that flower shop' owners have invested in packaging, baskets, and accessories that complement the flowers' product in a purchase. Also, in certain stores, the affective and artistic value of each bouquet or arrangement has been added, increasing the final price of the product, but providing more satisfaction to the customer by purchasing a differentiated product. Another interesting observation is that acquisition of complete decoration for events, it is the less sold item by the retailers. Nowadays, this consists in a distinct segment, named Decoration, which is specialized in this kind of service. Another observation concerning about sales of one single flower stem, that was mentioned by $23,5 \%$ of the interviewed and consist as an important item for commercialization.customers, $40.5 \%$ indicated that usually looking for products to impress, but with reduced price (Figure 13). 


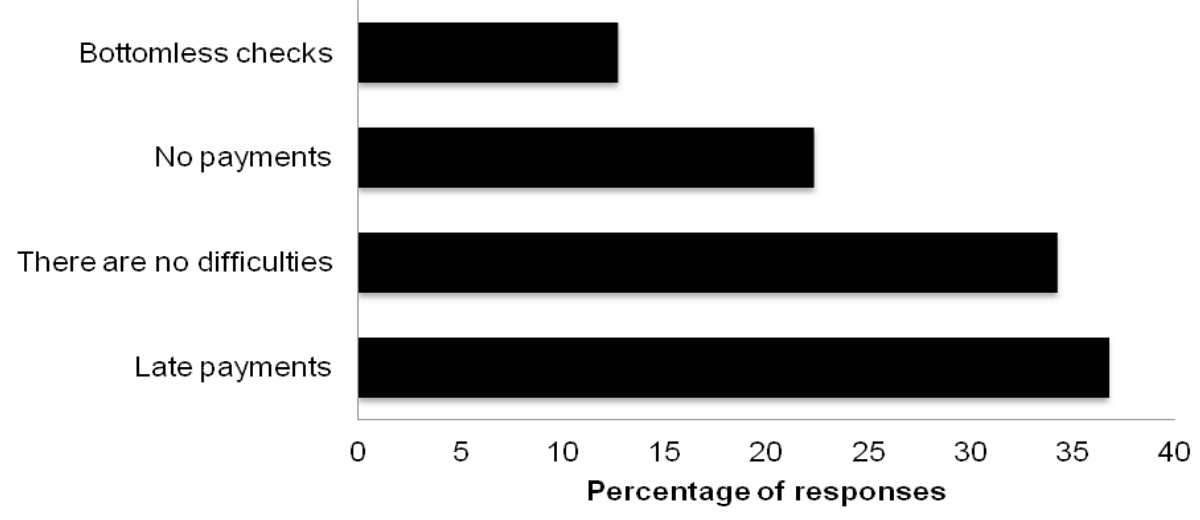

Figure 13. Customers behavior in a purchase, according to the owners of the flower shops.

It could be seen that a small portion of the customers do not care about the value of the product, but rather to impress the one who will be graced (Figure 13) The majority looks for products with low prices $(63.3 \%)$, showing that flowers and ornamental plants are still considered a simpler product or even just used as a compliment. Among the interviewed, $37.7 \%$ of the flower shop owners answered that customers prefer to buy flowers' bouquet with 6 to 12 stems (Figure 10), indicating a kind of preference of gifting with flowers, with an average bouquet size, just enough to impress.

Some factors that influence the consumption of flower and ornamental plant, such as, income level of the population, that is, the higher income, the greater the consumption (Anacleto et al., 2017b). Also, the possibility of contact with nature can also influence: greater is this contact, lower the consumption of flower and ornamental plant. Thus, in large cities, where there is less contact with nature and a higher income of the population, there was observed higher consumption. On the other hand, in smaller cities, where there is a larger share of elderly people in the population, consumption may also be higher (Aki, 2002).

Regarding the limitations informed by the customers, for $36.7 \%$ indicated that delay in payment is a problem and for $22.3 \%$, non-payments. Despite this, $34.2 \%$ of the owners do not have difficulties with customers, mainly due to the prompt payment used (Figure 14).

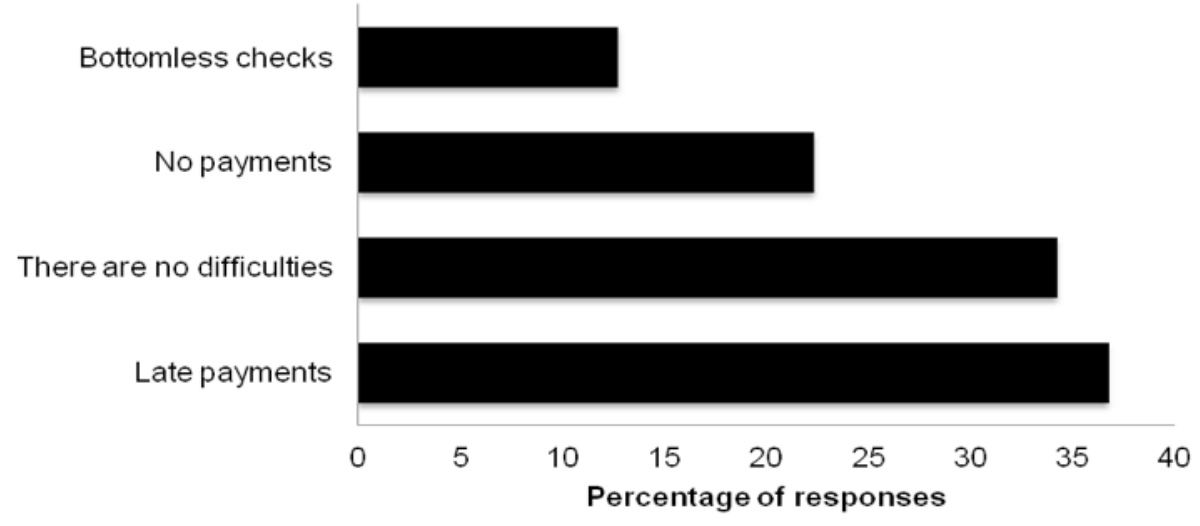

Figure 14. Limitation or problems in relation to customers, according to the flower shops owners.

In addition to the formal sales, a significant number of companies are using digital marketing as social networks and websites, to increasing the products sales and attract customers (Figure 15). This shows that the digital era is also influencing the flower and ornamental plant sector, as an innovation, even though consisting of an important new channel for the commercialization of the products. 


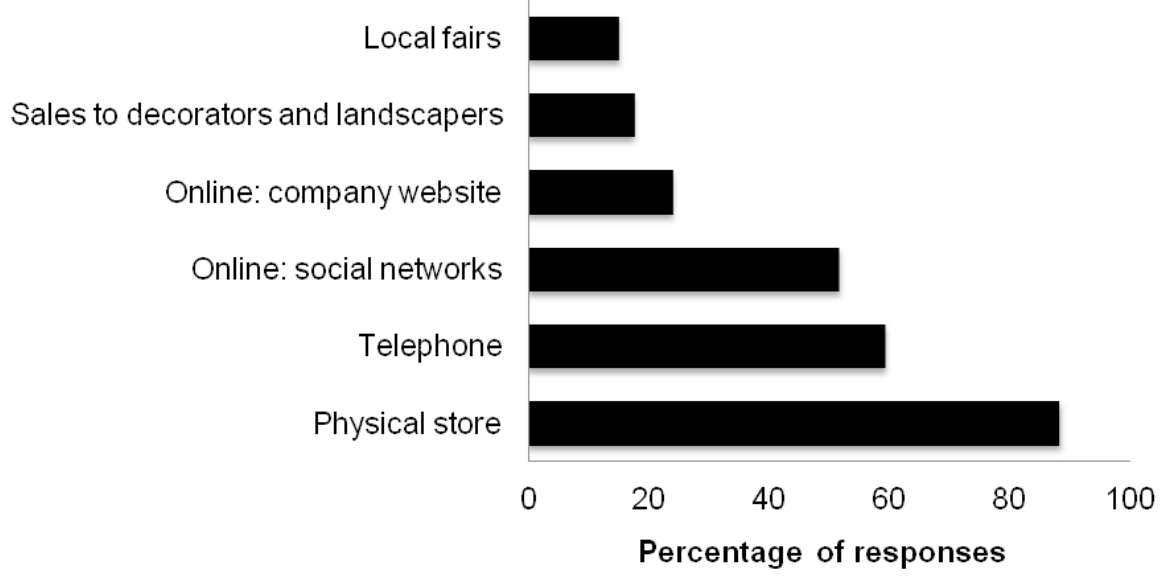

Figure 15. Most used product commercialization options by the flower shop owners (multiple responses).

Through the social networks, such as Facebook, Instagram, and WhatsApp, customers have access to photos and details of products offered by the flower shop. Also, there is the convenience of choosing online the product and be delivered directly in-home or to someone who will be gifted. Selling online is a way to increase the sales reach, in addition to making life easier for the customer, who does not need to leave home or work or either, if they are home absent (Rombach and Bitsch, 2016).

The owners were asked to inform about the use of the customer directory. Surprisingly, it was observed that the majority either do not have this or do not use this tool (Figure 16). This type of information can be important to retain customers since it allows establishing a direct connection between the store and the customers. Some interesting actions that may be done by the shop owner and lead to delight the customers by remembering special dates, such as birthdays, wedding dates, and others, when are coming up. Thus, the customer is encouraged to purchase flower products and also, feels very satisfied because they did not forget an important date.

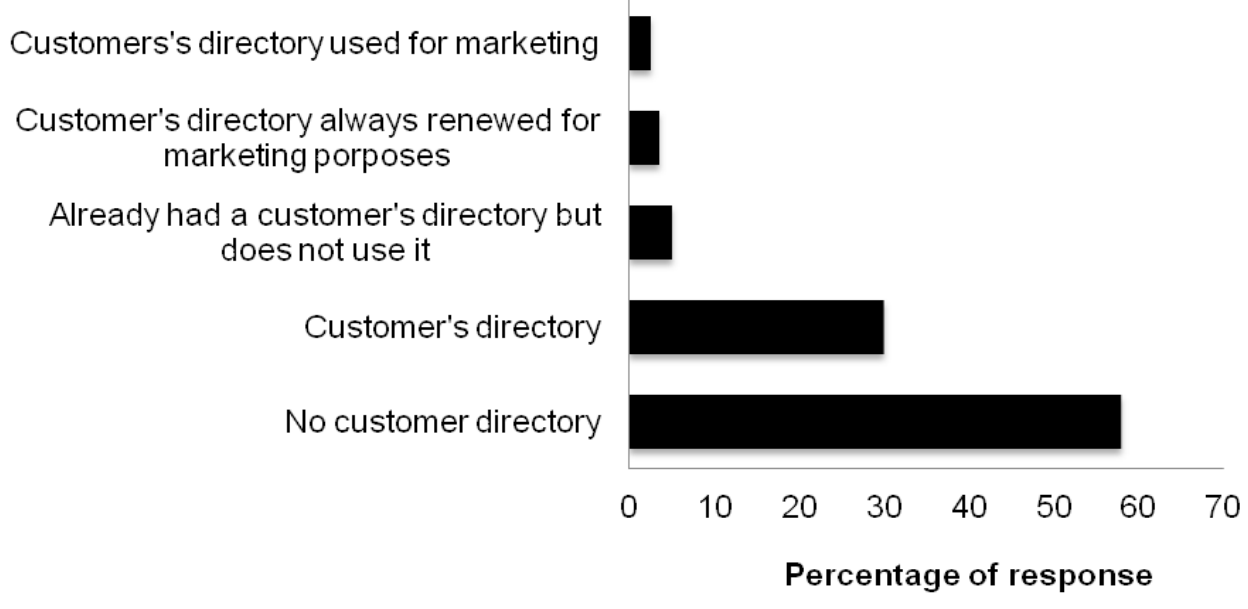

Figure 16. Use of customers directory by the flower shop owners (multiple responses).

The adoption of marketing strategies for the promotion of the store and products was also addressed in the questionnaire, requesting the respondents to inform which resources they have been using. Thus, $37 \%$ of respondents said that do not advertise their business, $29 \%$ only sporadically, and 15\% always use marketing strategies to increase sales. Flower marketing is an essential action to promote a flower shop, allowing the announcement of the products, motivating the purchase, and retain the customer. 
Considering the company's structure, in the last 5 years, $32.9 \%$ increased the physical structure and $20.3 \%$ invested in the expansion of the area and also in products diversity (Figure 17A). This is a good result of the latest years of development of the flower and ornamental plant sector. Also, it shows that companies have been following the trade market development, giving to their stores a greater variety of products, more space, and comfort to fulfill customer demand.
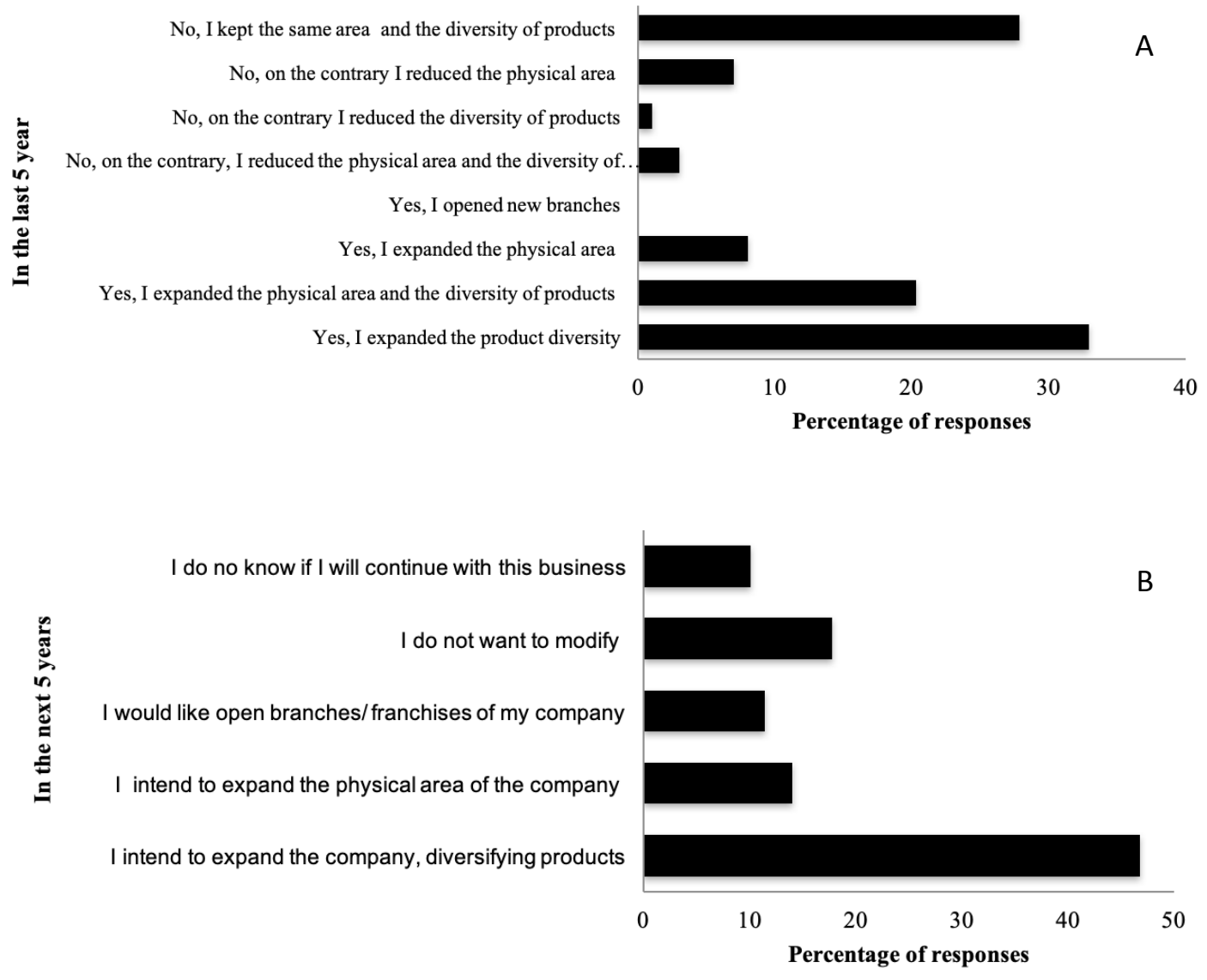

Figure 17. The company's structure in the last 5 years (A) and for the next 5 year (B).

The trade market shows a promising future, even with the economic crisis suffered in 2017, the flower business continued to grow in 2018 (Junqueira and Peetz, 2018). Observing this optimistic situation of the sector, it was mentioned by more than $60.7 \%$ of flower shop owners the aim of expanding their business by diversifying products and increasing physical area. Showing that, despite the limitations, this is an activity with a good perspective of grown (Figure 17B). But for $10.1 \%$ of the entrepreneurs interviewed, they are not sure whether will continue owning this business in the next five years, even with the indications of trade market growth. This may be a reflection, for example, of the lack of interest in improving product promotion, or even the costs for maintaining a store.

\section{Conclusions}

Although the great majority of producers of flower and ornamental plant have family production as a strong characteristic, and that it has been passed down from generation to generation, the number of new productions has been increasing. The main reason for flower shops to start this business is the potential trade market and affinity of this field of work. The beginning of Spring season has been considered a new important moment for commercialization of flower and ornamental. The majority of flower shops still do not use a customer's directory system, as well as not investing in business marketing and advertising. The main way for product commercialization is in physical stores, but the use of technology for online sales is a rising alternative. 


\section{Author Contribution}

M.V.R.: idea, project and survey design, questionnaire application, interpretation of the results, manuscript writing, and review. G.S.S.: survey design, questionnaires application, statistical analyses, interpretation of the results, manuscript writing. P.D.O.P.: idea, project and survey design, questionnaires application, interpretation of the results, manuscript writing, and review. F.L.B.: interpretation of the results and manuscript writing. P.H.S.G.: statistical analyses and manuscript writing.

\section{Acknowledgments}

The authors are thankful to CNPq, Capes and Fapemig for the scholarships. Also, we would like to acknowledge the VeilingHolambra, Cooperflora, Ibraflor, SBFPO, and Nepaflor for disseminating the questionnaires.

\section{References}

ANACLETO, A. Flowers supply chain in Paraná Coast - Brazil: an application of Miles and Snow taxonomy. Revista Capital Científico, v.14, n.1, p.10-25, 2016.

ANACLETO, A.; NEGRELLE, R.R.B.; CUQUEL, F.L.; MURARO, D. Profile and behavior of flower consumer: subsidies for marketing actions. Revista Ceres, v.64, n.6, p.557-566, 2017. DOI: http://dx.doi. org/10.1590/0034-737x201764060001

ANACLETO, A.; FUJITA, E.S.; MENDES, L.P.; VIEIRA, R.M.; PEREIRA, R.T. Profile and behavior of elderly flower consumer in Paraná Coast. Ornamental Horticulture, v.23, n.3, p.337-344. 2017b. DOI: http:// dx.doi.org/10.14295/oh.v23i3.1029

AKI, A. Bússola da Comercialização para Produtores de Ornamentais. Holambra: Heliza, 2002. 179p.

CERATTI, M.; PAIVA, P.D.O.; SOUSA, M.; TAVARES, T.S. Comercialização de Flores e Plantas Ornamentais no segmento varejista no município de Lavras/MG. Ciência e Agrotecnologia, v.31, n.4, p.1212-1218, 2007.

IBRAFLOR. Instituto Brasileiro de Floricultura. Mercado de Flores. Available at: https://www.ibraflor.com.br/. Access June 20 2019.

IBGE. Instituto Brasileiro de Geografia e Estatística. Available at: http.//www.ibge.gov.br/. Access May 20 ${ }^{\text {th }}$, 2020.

JUNQUEIRA, A.H.; PEETZ, M.S. Brazilian consumption of flowers and ornamental plants: habits, practices and trends. Ornamental Horticulture, v.23, n.2, p.178-184, 2017. DOI: http://dx.doi.org/10.14295/oh.v23i2.1070
JUNQUEIRA, A.H.; PEETZ, M.S. O setor produtivo de flores e plantas ornamentais do Brasil, no período de 2008 a 2013: atualizações, balanços e perspectivas. Ornamental Horticulture, v.20, n.2, p.115-120, 2014.

JUNQUEIRA, A.H.; PEETZ, M.S. Sustainability in Brazilian floriculture: introductory notes to a systemic approach. Ornamental Horticulture, v.24, n.2, p.155162, 2018. DOI: http://dx.doi.org/10.14295/oh.v24i2.1253

LAKSHMI, V.V.; NIHARIKA, D.A.; LAHARI, G. Impact of gender on consumer purchasing behaviour. Journal of Business and Management, v.19, n.8, p.33-36, 2017.

LANDGRAF, P.R.C; PAIVA, P.D.O. Produção de flores cortadas no estado de Minas Gerais. Ciência e Agrotecnologia, v.33, p.120-126, 2009a.

LANDGRAF, P.R.C; PAIVA, P.D.O. Produção de mudas para jardim no estado de Minas Gerais. Ciência e Agrotecnologia, v.33, p.127-131, 2009b.

LI, Y.; LEI, M. Analysis on development pattern and marketing strategy of flower e-commerce of personalized customization - A case study of the Beast. Open Journal of Business and Management, v.4, n.1, p.60-66, 2016. DOI: https://doi.org/10.4236/ojbm.2016.41007

PADMINI, S.M.P.C.; KODAGODA, T.D. Present status and future scope of Floriculture industry in Sri Lanka and its potential in women empowerment. Sri Lanka Journal of Social Sciences, v.40, n.1, p.31-40, 2017. DOI: https:// doi.org/10.4038/sljss.v40i1.7499

PUSA, K., GIRIBABU, M. Floriculture and the role of women in Nagaland: A case study. Arthshastra Indian Journal of Economics \& Research, v.5, n.6, p.4252. 2016. DOI: https://doi.org/10.17010/AIJER/2016/ V5I6/107524

ROMBACH, M.; BITSCH, V. A typology of online flower shops on the German market. Acta Horticulturae, n.1132, p.127-134, 2016. DOI: https://doi.org/10.17660/ ActaHortic.2016.1132.17

SILVA, L.C.; PAIVA, P.D.O.; SANTOS, A.C. Flower and ornamental plants wholesale markets in Brazil. Ornamental Horticulture, v.21, n.1, p.53-62, 2015. DOI: https://doi.org/10.14295/rbho.v21i1.776 